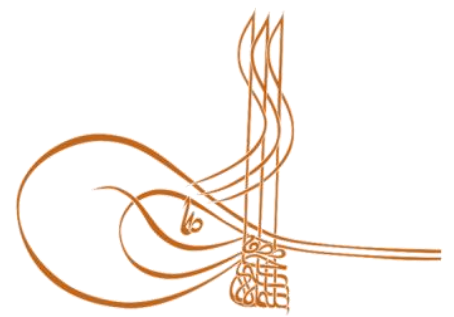

www.turkishstudies.net/economy
Turkish Studies - Economics, Finance, Politics

eISSN: $2667-5625$

Research Article / Araştırma Makalesi

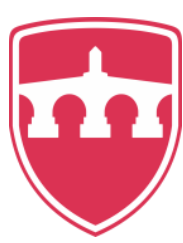

INTERNATIONAL BALKAN

UNIVERSITY

Sponsored by IBU

\title{
Türkiye'de 24 Haziran 2018 Genel Seçimleri Sonrasında "Topal Ördek” Tartışması: Cumhurbaşkanlığı Hükümet Sisteminde Olası Riskler ve Karşı Çözümler
}

\author{
"Lame Duck" Debate In Turkey After June 24, 2018 General Elections: Possible Risks And Against \\ Solutions In The Presidential Government System
}

\author{
Berat Akınci*
}

\begin{abstract}
The government system discussions began in Turkey after 1970's has ended with the adoption of the presidential government system with referendum held on April 16, 2017. The presidential government rising on the foundations of the presidential system in full struggle with the various guardianship focuses and ending the administrative and political crisis of Parlimenter system specific to Turkey aims to eliminate obstacles that leads to a democracy deficit including the election of the executive and legislative powers in particular.While some regulations integrated into the new system immediately were implemented with the referendum, the full implementation of the system was possible with the June 24 general elections. However, immediately after the June 24 elections, the Republican People's Party (CHP) chairman Kemal Kılıçdaroğlu claimed that the president, who was the head of the executive power, was facing the "lame duck" case of the United States (US) type presidential system. Such a situation emerges when the successor-predecessor presidents in the United States have a different political majority in terms of executive power and the period spent during the change of duties. The concept of lame duck, which is at the center of the debate, was defined as someone who could not pay off the debt in England in the 18th century, and in time, it was used in the sense of a manager with limited authority. Therefore, this study will analyze how the political picture formed after the first general elections of the new government system overlaps with the 'lame duck' case expressed by the opposition parties. In addition, it will be emphasized that whether the discussions stem from political reasons or the structural problems of the new government system and what counter-solutions about the topic are brought in the new system.
\end{abstract}

Structured Abstract: Parliamentary system of government that is being implemented in Turkey, considering the performance outcomes expected of him revealed a failure to fulfill any function is observed. All countries, while global arena dizzy entered executive branches against the changes to the race strong and effective hold time and place feet ability to adapt, managerial crisis spiral and can not be solved somehow

\footnotetext{
* Dr. Öğr. Üyesi, Adana Alparslan Türkeş Bilim ve Teknoloji Üniversitesi, Siyasal Bilgiler Fakültesi, Uluslararası İlișkiler Bölümü

Asst. Prof. Dr. Adana Alparslan Turkes Science and Technology Unlversity, Faculty of Political Sciences, Department of International Relations ORCID 0000-0002-5239-5417

beratakinci@yahoo.com, bakinci@atu.edu.tr

Cite as/ Atıf: Akıncı, B. (2020). Türkiye'de 24 haziran 2018 genel seçimleri sonrasında "topal ördek" tartışması: Cumhurbaşkanlığı hükümet sisteminde olası riskler ve karşı çözümler, Turkish Studies - Economy, 15(1), 9-21. https://dx.doi.org/10.29228/TurkishStudies.40187

Received/Geliş: 16 December/Aralık 2019

Accepted/Kabul: 25 March/Mart 2020

Copyright (C) INTAC LTD, Turkey

Checked by plagiarism software

Published/Yayın: 30 March/Mart 2020

CC BY-NC 4.0
} 
their problems Turkey has moved away day by day to show strong reflexes against what is happening around the. In a referendum held on April 16, 2017 Turkey did not remain indifferent to this situation founded on the basis of the US presidential system "Presidential System of Government" has the green light. The new system, which started to be implemented fully with the general election of June 24,2018 , opened the door to multi-dimensional debates that started over the legislative-executive-judicial powers before the referendum and finally gained a new dimension for President Erdogan after the election results of the opposition parties. Although the concept of lame duck appeared in England, it has become a concept that expresses the fact that the president lost his majority in the USA against the congress by moving to the political field. However, if the president elected for two terms with four-year terms, either his successor at the end of the first or the second term, the situation until the new president begins his duty is defined as a lame duck.

In Turkey, the CHP leader Kemal Kılıçdaroğlu, June 24, 2018 legislative-executive lame duck debate that began in the elections in the wake of powers, Prime Minister Recep Tayyip Erdogan March 31 local elections against over results "lame duck" has continued with the output. The theses put forward by both leaders regarding the lame duck case consist of the political evaluation of the election results. When the arguments of opposition parties on this issue are analyzed, the new government is based on the fact that the majority of the parliament is against the president's party rather than the change of the president, since it is the first general election of the system. Opposing parties from this point argue that the results of the elections of the legislative-executive powers of June 24, 2018 were similar to the "lame duck" case in which the president lost his congressional majority in the presidential system. However, with the new government system, as a result of the changes made in the election laws, it became possible for political parties to enter the elections by forming an alliance. Therefore, although Ak Party, which is the party of President Recep Tayyip Erdogan, could not achieve the majority in the parliament alone, the fact that the republic's alliance with MHP won the majority in parliament leaves this argument in the air for now. On the other hand, the absence of a regulation that the alliances would continue without interruption during an election period necessitates that every political party that wins the presidential race should also come out with absolute victory in the legislative power. Otherwise, the risk of "lame duck" happening in the style suggested by the opposition parties will be quite high. In order to minimize this risk, it is crucial that political parties implement practices that will strengthen their existing election alliances as soon as possible.

In the end stage of constructing the new system taking into consideration Turkey's political structure, the executive president's hand sooner thanks to some adjustments to strengthen the "lame duck" status it is intended to prevent falls. In this context, if the president's party fails to obtain a sufficient majority in the parliament, many problems are eliminated with the new system, thanks to the powers granted to the president, from the budget crises that could lead to the system to be locked in the US presidential system, to the appointment of ministers and senior public officials, and even to the renewal of the elections. Presidential System of Government in exchange of its predecessor-successor to the president kept very short period of time according to the US presidential system "lame duck" in our case stands as a barrier against the formation of regulations in Turkey. However, implementation of the new system of government with a president, until it is Turkey "lame duck" went through many test cases will be subject to discussion and as should be expected.

Keywords: Lame Duck Case, Presidential System, Presidential Government System.

Öz: Türkiye'de 1970'li yıllardan sonra başlayan hükümet sistemi tartışmaları, Cumhurbaşkanlığı Hükümet Sistemi'nin 16 Nisan 2017 tarihinde yapılan referandumla kabul edilmesiyle son bulmuştur. Parlamenter sistemin Türkiye'ye özgü yönetsel ve siyasal krizlerini sonlandırmak ve çeşitli vesayet odaklarıyla tam mücadele kapsamında başkanlık sistemi temelleri üzerine yükselen Cumhurbaşkanlığı Hükümet Sistemi, başta yasama ve yürütme erklerinin seçimi de dahil olmak üzere demokrasi açığına sebep olan engelleri ortadan kaldırmayı amaçlamıştır. Referandumla birlikte yeni sisteme entegre bazı düzenlemeler hemen hayata geçirilmiş iken, sistemin tam anlamıyla uygulanması 24 Haziran 2018 genel seçimleriyle mümkün olabilmiştir. Ancak 24 Haziran seçimlerinin hemen akabinde Cumhuriyet Halk Partisi (CHP) Genel Başkanı Kemal Kılıçdaroğlu tarafından yürütme erkinin başı olan cumhurbaşkanının, Amerika Birleşik Devletleri (ABD) tipi başkanlık sistemi uygulamasında görülen "topal ördek" vakasıyla karşı karşıya olduğunu ileri sürmüştür. ABD’de yürütme erki açısından halef-selef başkanların görev değişimi esnasında geçirilen dönem ile yasama ve yürütme erklerinin farklı siyasi çoğunluğa sahip olmaları durumunda böylesine bir tablo ortaya

Turkish Studies - Economy, 15(1) 
çıkmaktadır. Tartışmaların öbeğinde yer alan topal ördek kavramı ise 18. yüzyılda İngiltere'de borcunu ödeyemeyen birisi olarak tanımlarken, zamanla politik alana geçerek yetkileri sınırlandırılmış yönetici anlamında kullanılmaya başlanmıştır. Dolayısıyla bu çalışmayla yeni hükümet sisteminin ilk genel seçimleri sonrasında oluşan siyasi tablonun, muhalefet partileri tarafindan dile getirilen "topal ördek" vakasıyla ne kadar örtüştüğü analiz edilmiştir. Ayrıca yapılan tartışmaların politik gerekçelerle mi yoksa yeni hükümet sisteminin yapısal sorunlarından mı kaynaklandığı ortaya koyularak, konuyla alakalı yeni sistemde ne gibi karşı çözümler getirildiği üzerinde durulmuştur.

Anahtar Kelimeler: Topal Ördek Vakası, Başkanlık Sistemi, Cumhurbaşkanlı̆̆g Hükümet Sistemi.

\section{Giriş}

Türkiye'de yaklaşık bir asırı bulan uygulamasıyla yönetsel ve siyasi istikrar açısından beklenen işlevini yeterince yerine getiremeyen parlamenter sistem, özellikle 1970'li yıllardan sonra yürütme erkinin iki başının da göreve başlaması noktasında ortaya çıkan krizlere kalıcı çözüm üretememiştir. Her ne kadar siyasal sistemin en önemli elamanlarından birisi hükümet sistemi olsa da, oluşan kaos ortamının tek sebebini hükümet sistemlerinde aramak siyasal sistemin tamamlayıcı unsurlarını yok saymamız anlamına gelmektedir. Dolayısıyla her ülke kendine uygun hükümet sistemini belirlerken, siyasal sistemin diğer enstrümanlarıyla birlikte kendi tarihsel geçmişini, politik ve yönetsel geleneklerini, kültürel ve sosyolojik yapısını dikkate almak zorundadır. Bu yüzden dünya ölçeğinde aynı hükümet sistemiyle yönetilen ülkelerde bile farklı uygulamaların ve sonuçlarının olması ülkelerin yapısal farklılıklarının doğal bir sonucudur. Örneğin parlamenter sistem İngiltere'de başarılı bir performans ortaya koyarken, Türkiye'de krizlerle geçen çok farklı bir geçmişe sahip olmuştur. Bu kadar kaotik uygulamalara kapı aralayan parlamenter sistem nihayetinde 16 Nisan 2017 tarihinde yapılan referandum ile yerini Cumhurbaşkanlığı Hükümet Sistemi'ne bırakmıştır (Yıldırım, 2017:143-149).

Devletin temel erkleri arasında yönetsel ve siyasi istikrarı sağlayarak demokrasinin konsolide edilmesini amaçlayan yeni sistem, 24 Haziran 2018 tarihinde yapılan "Cumhurbaşkanlığı ve Milletvekili Genel Seçimleri" ile birlikte tam olarak uygulanmaya başlamıştır. Başkanlık sisteminin temel özellikleri üzerine yükselen cumhurbaşkanlığı hükümet sistemi, diğer ülke uygulamalarında ortaya çıkan sorunları da göz önünde bulundurarak Türkiye'ye özgü tasarlanmıştır. Yeni sistemin referandumla kabulü öncesinde hayır bloğu partileri tarafindan tek adam iktidarı, yasama ve yargı erklerinin yürütmenin etkisi altına gireceği ve cumhurbaşkanının parti üyeliğinin devam etmesinin tarafsızlık ilkesine aykırı olacağı üzerine eleştiriler yapılmıştır. Bununla birlikte yeni hükümet sistemiyle siyasal sistemin değişeceği ve federatif yönetim sistemine zemin hazırlandığına yönelik de itirazlar son derece yüksek perdeden dile getirilmiştir (Akınc1, 2019:87-124).

Tüm bu eleştirilerin ötesinde 24 Haziran 2018 seçimlerinin hemen akabinde başlayan ve Ak Parti iktidarının özelinde Cumhurbaşkanı Recep Tayyip Erdoğan'ın güç kaybederek "topal ördek" durumuna düştüğü tezi, Mart 2019 yerel yönetimler seçim sonuçlarıyla zirve yapmıştır. Bu tez evveliyatında CHP Genel Başkanı Kılıçdaroğlu tarafından dile getirilse de akabinde millet ittifakı ve diğer partiler tarafından da destek bulmuştur. Topal ördek kavramı İngiltere'de mali durumları kötüye giden ve iflasın eşiğine gelen şirketler için kullanılmakta iken, 1800'lü yıllardan sonra politik ortama taşınarak yetkileri sınırlandırılmış yönetici olarak tanımlanmıştır. Başkanlık sisteminin ABD uygulamasında kavramın somut halinin görülebileceği farklı senaryolar mevcuttur. $\mathrm{Bu}$ çalışmada ABD'de yasama-yürütme erklerinin seçimleri öncesi ve sonrasında politik kaygılara sebep olan "topal ördek" vakasının cumhurbaşkanlığı hükümet sistemi açısından benzer bir risk oluşturup oluşturmadığ karş1 çözümler üretildiği üzerinde durulmuştur. 


\section{Topal Ördek Kavramı ve Başkanlık Sistemi}

Topal ördek kavramı her ne kadar parlamenter sistem ile özdeşleşmiş bir kavram değilse de, ABD tipi başkanlık sistemi uygulamasında oldukça yaygın kullanılan bir kavramdır. Kavramın kökeni 18. yüzyıl İngiltere'sine kadar gitmekle birlikte, zamanla boyut değiştirerek sınırları aşmış ve başkanlık sisteminde yasama-yürütme ilişkilerindeki politik durumları dile getiren bir anlam kazanmıştır.

\subsection{Topal Ördek Kavramı}

Topal ördek kavramı içinde bulunulan bir durumun olumsuzluğunu anlatmak amaciyla kullanılmaktadır. Kavram bu haliyle doğal ortamda bir kusuru veya açığı sebebiyle yara almış kolay bir av hayvanını tanımlayabileceği gibi, mecazi anlamda baskılara direnemeyen taviz vermeye hazır insan, şirket, kurum, hükümet veya ülke anlamında da kullanılabilmektedir. Nihayetinde farklı gerekçelerle topal ördek konumuna düşmüş kişiler-kurumlar, bu hale düşmeden önce bağlayıcı, güçlü, kapsayıcı ve ileri vadeli verebileceği kararları yetkilerinin kısıtlanması veyahut yeni şartlar gereği verememektedir (Cambridge Dictionary).

Kavramın çıkış noktası 18. yüzyılda Londra'da borçlarını ödeyemeyen birisine veya borsacıya "Topal bir ördek gibi sokağın ortasında dolaşmak zorunda kaldı" ifadesine dayanmaktadır. Dolayısıyla kavramın ifade ettiği kişiler-kurumlar genellikle yaptıkları işlerde başarısız olanlar ve güçlerini kaybedenlerdir. Bununla birlikte yetkileri devam etmekle birlikte, belirli bir zaman içerinde bu yetkileri devredecek olan kişi de topal ördek kavramıyla tanımlanmaktadır. Örneğin hâlihazırda görevde olan ancak seçimler yoluyla halefi belirli olan kişilerle, emeklilik veya kesin sürelerin öngörüldüğü sınıra yaklaşmış kişilerde topal ördek olarak adlandırılmaktadır. Nihayetinde topal ördek vakasının gerçekleşmesi belirli bir geçiş sürecine karş111k gelmektedir (Amedo, 2019) .

Siyaset bilimi literatürü açısından kavramın politik alanda ilk olarak ABD Başkanı Abraham Lincoln'ün selefi konumunda olan James Buchanan'a "topal ördek" ifadesini kullanmasıyla başladığı ileri sürülmektedir. Aslında kavram ABD’nin siyasal ve hükümet sistemi ile anayasal sisteminin ortaya koyduğu sert kuvvetler ayrılığı ile de yakından ilgilidir. Dolayısıyla kavramın kökenini "kuvvetler ayrılı̆̆ı" ilkesinin ortaya çıkmasına öncülük eden Aristo'dan Montesquieu'ya kadar götürmek yanlış olmayacaktır. Devletin sahip olduğu temel erklerin sert bir şekilde ayrıldığı ABD'de, yasama erki olarak Senato ve Temsilciler Meclisi'nden oluşan Birleşik Devletler Kongresi, yürütme erki olarak Başkan ve Kabinesi, yargı erki ise bütün demokratik ülkelerde olduğu gibi bağımsız Yüksek Mahkeme ve alt derece mahkemelerinden oluşmaktadır (Kuzu, 2013:19-43; Amedo, 2019).

ABD başkanlık sistemi uygulamasında yürütme erkinin başı konumunda olan başkanın seçimler sonucunda halefinin seçilmesi ve kongrede sahip olduğu çoğunluk desteğini kaybetmesi literatürde "topal ördek" (lame duck) vakası olarak kavramsallaştırılmaktadır. Nihayetinde bölünmüş hükümet görüntüsü altında başkan, görev alanıyla alakalı konularda çalışırken hiçbir zaman eskisi kadar rahat olmayacaktır (Gülener, 2016:7-50). ABD'de Amerikan Anayasası'na eklenen ve "Topal Ördek Yasası" diye bilinen 20. Anayasa değişikliği her y1l 6 Şubat'ta "Topal Ördek Günü” olarak kutlanmaktadır. Her ne kadar topal ördek dönemindeki başkanların iç politikaya dönük ve çok bir şey yapmamaları beklense de, bazı başkanlar bu beklentileri aşarak kişisel siyasi miraslarını güçlendirmek için çaba harcadıkları ileri sürülmektedir (Potter, 2016; Johnson, 1986:50-65).

\subsection{Başkanlık Sisteminde Topal Ördek Vakası}

Kuvvetler ayrılığı prensibine uygun olarak dizayn edilen başkanlık sistemi, parlamenter sistemin tarihi serüvenine sahip değildir. Bu bağlamda parlamenter sistem uzun ve meşakkatli bir yolculuğun sonunda ancak İngiltere'de kök salabilmiştir. Başkanlık sistemi ise geçmişi bu kadar 
eski olmamakla birlikte 1787 yllında toplanan ABD kurucu meclisinin müzakereleri sonunda ülkenin yapısal durumuna en uygun sistem olarak kabul edilmiştir. Sistemin özelliği gereği devletin erkleri arasında net bir ayrım söz konusudur. Özellikle yasama-yürütme erkelerine tanınmış olan denge ve fren mekanizmaları birbirlerinin alanına doğrudan müdahale etmeden demokrasinin işleyişine olanak vermektedir. Dolaylı olarak erklerin birbirlerini kontrol etmesi ve gözetlemesi, yasama ve yürütme erklerinin faaliyet alanlarında sağlıklı kararlar verebilmesine de katkı sunmaktadır (Eren ve Akıncı, 2018:35-71).

Başkanlık sistemin temel özelliklerine bakıldığında kuvvetler ayrılığı prensibine uygun olarak yasama ve yürütme erklerinin seçimle iş başı yaptığı görülmektedir. Dolayısıyla her iki erkte meşruiyetini doğrudan milletten aldığı için birbirlerinin varlığına son verememektedir. Meşruiyetin sürekli güncel tutulması ve siyasi konjonktürün her daim temsil edilmesi bakımından, yasamayürütme seçimleri farklı tarihlerde gerçekleşmektedir. Senato üyelerinin 1/3'ünün her iki yılda bir değiştiği başkanlık sisteminde, başkan 4 yıllığına seçilmekte ve yasalara karşı işlemiş olduğu suçlardan dolayı kongre tarafından suçlandırılıp (impeachment) mahkûm edilmediği sürece görevinde kalmaktadır. Bu noktadan sistemin özelliği gereği farklı tarihlerde yapılan seçimlerden dolayı, başkanın hem senatoda hem de temsilciler meclisinde çoğunluğunu kaybetme riski bulunmaktadır. Yasama-yürütme çoğunluğunun aynı siyasi partide olması, erklerin ahenkli çalışmasını kolaylaştırmaktadır. Ancak erklerin farklı siyasi parti çoğunluklarında olması durumunda ise başkanın rahat çalışması senato veya temsilciler meclisi tarafindan engellenecek, bu durumda başkanın topal ördek konumuna düşmesine sebep olacaktır (Sartori, 1997:114-116; Kahraman, 2012:430-456; Parsak, 2012:1-20).

ABD başkanlık sisteminde hem başkan hem de kongre açısından topal ördek olarak sayılan durumlar şunlardır (Johnson, 1986:50-65; Amedo, 2019; Yaman, 2014:83-98):

Sistemin başkanlar için sabit bir görev süresi ve iki dönem seçilebilme hakkı belirlemesi, yürütmenin alanına giren faaliyetlerde acele davranmasına sebep olmaktadır. Siyasi ajandasında yazılı vaatleri yerine getirmek isteyen başkan, tekrar seçilebilme ve zamanı iyi kullanabilme adına verimsiz kararlar alabilmektedir. Bu kararların başarısızlığ 1 ve ikinci dönem sonunda tekrar seçilemeyecek olması başkanın durumunun "topal ördek" olarak nitelenmesine sebep olmaktadir.

$\checkmark \quad$ Başkanın halefinin kasım ayında tam olarak belirlenmesinden sonra, yeni başkanın koltuğuna geçinceye kadar geçen 3 aylık sürede selef başkan topal ördek olarak tanımlanmaktadır. Başkan bu dönemde genellikle geçiş sürecini yönetir ve devlet işlerinin yürümesini sağlayan sıradan işlerle uğraşarak süresini doldurmaktadır.

Başkanlık sisteminde en hassas topal ördek dönemi şüphesiz başkan ile kongrenin farklı siyasi çoğunluktan gelmiş oldukları dönemdir. Bu dönemde kongre desteğini yitirmiş başkan, kimilerine göre oturan ördek olarak da nitelendirilmektedir.

Kasım ortasında yapılan kongre seçimleri sonrasında yeni seçilen üyeler birkaç hafta sonra yemin ederek görevlerine başlamaktadır. Yeni üyeler başlayıncaya kadar eski üyeler görevlerine devam etmektedir. $\mathrm{Bu}$ süre içerisinde kongrenin eski üyelerle yapmış olduğu toplantılara "topal ördek toplantısı" denilmektedir. Kongre 2000 y1lından itibaren bu toplantıları düzenli bir şekilde yapmakta olup, toplantılarda daha önce farklı gerekçelerle kararlaştıramadıkları konuları oylayabilmektedir. Ancak en önemli toplantılarından bir tanesi de 1 Ekim'e kadar onaylanması gerekirken onaylanmamış federal bütçenin görüşmeleridir. Kongre topal ördek toplantıs1 yapsa bile yürütme erkinin faaliyetlerine devam edebilmesi için acil durum fonlarını da onaylamaktadır. Burada sıkıntı yaratan husus özellikle tekrar seçilemeyen kongre üyelerinin duygusal davranarak seçmenin istemeyeceği bir tasarıyı desteklemesidir. Bu yüzden topal ördek toplantıları üyelerin seçim sonrası beklentilerini önceleyen ve ekonomik gidişatta belirsizliğe yol açan uygulamaları ile hayal kırıklıkları yaratabilmektedir. 
ABD başkanlık sistemi uygulamasında oldukça sık karşılaşılan topal ördek dönemleri, kimi siyasiler tarafindan ölen bir devin acınacak son soluğu olarak görülmektedir. Yetkili kişiler bu dönemde kişisel arzularını güçleriyle kapatmaya çalışırken, plansız bir şekilde verimsiz kararlar vermektedir. Dolayısıyla topal ördek vakasına göre yeniden seçilemeyecek olan bir başkan, durumun psikolojik baskısıyla gücünü ve prestijini zamanla kaybetmektedir (Yazıc1, 2005:124143). Bu noktadan ABD tipi başkanlık sisteminde topal ördek konumunda olan başkan, yeni başkanın koltuğuna oturuncaya kadar karar yetkisini tam olarak kullanamamaktadır (Kohen, 2014).

ABD'de başkanın aynı çoğunlukta olmayan kongreyle çalışması neredeyse sıradan bir durum haline gelmiştir (Johnson, 1986:50-65). Bu bağlamda 20. yüzyılın başından günümüze kadar topal ördek vakası ABD'de $17 \mathrm{kez}$ tekrarlanmış ve özellikle 1970'den sonra bu durumun bir sonucu olarak bölünmüş hükümetler sıklıkla yer almıştır. 1969 tarihinden 2016'ya kadar geçen 47 senenin neredeyse yarısına karşıllı gelen dönemlerde Richard Nixon, Gerald Ford, Ronald Reagan, George Bush, Bill Clinton ve George W. Bush ve son olarak Brack Obama kendisine muhalif kongre ile çalışmak zorunda kalmıştır (Avcı, 2019).

Burada topal ördek vakasının ortaya çıkmasına sebep olan durumun nereden kaynaklandığının da altının çizilmesi gerekmektedir. Özellikle yasama ve yürütme erklerinin seçimlerinin zamanlaması ilk dikkat çeken husus olarak göze çarpmaktadır. ABD'de başkan ve kongre seçimlerinin farklı zamanlarda yapılıyor olması zamana göre değişen seçmen tercihlerinin temsilde adaleti sağlayacak şekilde realize edilmesini sağlamaktadır. Bu bağlamda 19. yüzyılda aynı döneme denk gelen başkan ve meclis seçimlerinde aynı parti lehine sonuçlanmıştır. Ancak başkanlık seçimlerine denk gelmeyen ara seçimlerde ise meclisin muhalif partinin hâkimiyetine girdiği görülmektedir. Dolayısıyla bölünmüş hükümetlere de yol açan "topal ördek" vakasının gerçekleşmesinde seçimlerin zamanlaması önemli bir yer tutmaktadır. Bununla birlikte yapısal düzenlemelerde sistemin doğal olarak topal ördek vakası ortaya çıkarma noktasında açıklarının da olduğu anlaşılmaktadır. Örneğin halef-selef değişimleri her ne kadar zamanla altı aydan üç aya düşürülse de, geçiş süresinin hala çok uzun olması bu olgunun zamanla sıradan bir durum olarak görülmesine sebep olmaktadır (Gülener, 2016:7-50).

\section{24 Haziran 2018 Genel Seçimleri Sonrası Türkiye'de Topal Ördek Tartışmaları}

ABD'de uygulanan başkanlık sisteminde sıkça dile getirilen "topal ördek" vakası; başkanın kongrede çoğunluğu yitirmesi ve görev süresinin bitmesi sonucunda halef başkanın koltuğuna oturuncaya kadar geçen dönemle özdeşleştirilmektedir. Başkan bu dönemde sıradan kamu hizmetlerini yerine getirerek geçiş dönemini yönetmektedir. Türkiye açısından geçmişte uygulanan parlamenter sistemde gündemde yer almayan bu kavram, 24 Haziran 2018 tarihinde yapılan genel seçimler sonucunda cumhurbaşkanlığı hükümet sistemiyle birlikte tartışılmaya başlanmıştır. $\mathrm{Bu}$ noktadan CHP Genel Başkanı Kılıçdaroğlu Merkez Yürütme Kurulu (MYK) toplantısı sonrasında yaptığı basın açıklamasında cumhurbaşkanı Erdoğan için "Dünün tek adamı bugünün topal ördeğidir. Her istediğini yapamayacak" ifadelerini kullanarak tartışmanın fitilini ateşleyen kişi olmuştur (Kılıçdaroğlu, www.haberturk.com, 2018).

\subsection{Topal Ördek Tartışmalarında Öne Çıkan Argümanlar}

Başkanlık sisteminde topal ördek vakası üzerinden yapılan tartışmalarda; yürütme erkinin seçimler yoluyla değişimi beklenilen bir durum olarak görülmekte iken, başkanın yasamadaki çoğunluğunu kaybetmesiyle birlikte erkler arasında olağandışı bir ilişki dönemi başlamaktadır. Türkiye'de de 16 Nisan 2017 referandumu ile kabul edilen cumhurbaşkanlığı hükümet sistemiyle, yasama-yürütme ilişkileri başkanlık sistemi temelleri üzerine inşa edilmiştir. $\mathrm{Bu}$ bağlamda kuvvetlerin (yasama, yürütme ve yargi) sert ayrımına tabi olan yeni sistem, bazı noktalarda Türkiye'ye özgü tasarımıyla ABD tipi başkanlık sisteminden ayrılmaktadır. 24 Haziran 2018 tarihinde yapılan genel seçimle birlikte Türkiye'de tam manasıyla uygulamaya geçen cumhurbaşkanlığı hükümet sisteminde, yasama ve yürütme erklerinin seçimleri halk tarafından 
yapılmaktadır. Böylelikle meşruiyetini doğrudan milletten alan yasama ve yürütme erkleri, birbirlerinin görev alanlarına müdahale edememekte ve erklere tanınmış denge ve denetleme araçlarıyla sistemin kriz üretmesi engellenmektedir. Yeni sistemle ayrıca yasama ve yürütme erklerinin istikrarlı çalışmasının temin edilmesiyle demokratik kazanımların konsolide edilmesi de amaçlanmıştır (Miş ve Duran, 2017:7-15).

Ancak cumhurbaşkanlığı hükümet sisteminin referandumla kabulü öncesinde hayır bloğu partileri tarafından sisteme yönelik bir takım eleştiriler yapılmıştır. Bu eleştirilerde tek adam yönetiminden, siyasi partilerin ve meclisin işlevsizleşeceğine ve hatta federatif yapıdan ülkenin siyasi rejiminin değişeceğine kadar birçok sıkıntı dile getirilmiştir. 16 Nisan referandumun millet tarafından kabulüyle birlikte bu eleştirilerin bir kısmı ortadan kalkmış, bir kısmı ise 24 Haziran 2018 yasama-yürütme erklerinin seçimleriyle birlikte pasifize olmuştur. Bu noktadan yeni sistemin ilk genel seçimiyle birlikte yasama-yürütme ilişkileriyle alakalı olarak bir takım yeni eleştiriler muhalif partiler tarafindan dile getirilmeye başlanmıştır. Bu eleştirilerin başında CHP Genel Başkanı Kılıçdaroğlu'nun cumhurbaşkanına atfen ortaya atmış olduğu "topal ördek" vakası yer almaktadır. CHP ve diğer muhalif partilerden yükselen topal ördek eleştirisi için ileri sürülen argümanlar şunlardır (K1lıçdaroğlu, 2018; Yüksek Seçim Kurulu (YSK, 2018; Erdoğan, 2019; Akşener, 2019; YSK, 2019; 7102 Sayılı Kanun):

24 Haziranda ittifaklar üzerinden girilen seçimlerde cumhur ittifakının cumhurbaşkanı adayı Recep Tayyip Erdoğan, \%52,59'luk oy oranıyla ilk turda seçilmiştir. Ancak yasama erkinin seçiminde hiçbir parti, yeni sistemde çoğunluğu sağlayabilmeleri için gerekli olan 301 sayısına ulaşamamıştır. Cumhur ittifakını oluşturan partilerden Ak Parti 295, MHP ise 49 vekil çıkarabilmiştir. Dolayısıyla cumhurbaşkanının partisi mecliste çoğunluğu elde edememiş ancak MHP'nin desteğiyle 301 sayısının üzerine çıkabilmiştir. Böylesine bir tablo başkanlık sisteminde başkan ile kongrenin aynı parti çoğunluğuna sahip olmadığı durumlarda ortaya çıkan topal ördek vakasına benzetilmektedir.

$\checkmark \quad 31$ Mart yerel seçimlerinde cumhur ittifakının \%51,64'lük oy oranıla açık ara seçimleri kazanmış olmasına rağmen, İstanbul, Ankara, Antalya, Adana ve Mersin gibi büyükşehirleri millet ittifakının almış olması yeni bir meşruiyet tartışması yaratmıştır. 23 Haziranda iptal edilen İstanbul seçimlerinin millet ittifakı adayının açık ara önde kazanması bu tartışmayı daha çok alevlendirmiştir. Ancak yerel seçimler sonrasında İstanbul da dahil bazı büyükşehirlerde cumhur ittifakı meclis üyelerinin sayısının seçimleri kazanan millet ittifakı üyelerinden fazla olması, Cumhurbaşkanı Recep Tayyip Erdoğan tarafından söz konusu belediye başkanlarını "topal ördek" olarak tanımlamasına sebep olmuştur. Her ne kadar ABD tipi başkanlık sisteminde bu durum yasama-yürütme arasında cereyan etse de, Cumhurbaşkanı Recep Tayyip Erdoğan yerel seçimlerde oluşan tablonun benzer sonuçlar ortaya koyacağını ileri sürmüştür.

Cumhurbaşkanlığı hükümet sisteminde gündeme gelen topal ördek tartışmalarında, başkanlık sisteminde görülen başkanın sabit görev süresi ve seçimler yoluyla değişiminde ortaya çıan geçiş dönemiyle alakalı bir gündem bulunmamaktadır. Ancak muhalif partiler başkanlık sisteminde yapılan ara seçimlerde siyasi konjonktürün sandığa tam yansıdığını belirterek, yeni sistemde seçimlerin eş zamanlı yapılmasının zamanla değişen seçmen tercihlerin temsilini engellediğini savunmaktadır. Dolayısıyla yeni sistemde genel seçimlerden sonra yapılan ve bir nevi ara seçim gibi partilerin son durumlarının ortaya çıktığı yerel seçimlerde, millet ittifakının önemli büyükşehirleri alması siyasi konjonktürün temsili noktasındaki itirazları daha da artırmıştır. Bu itirazlarda cumhurbaşkanının yasamadaki çoğunluğunun hali hazırda yapılacak olan bir seçimle değişebileceği ve cumhurbaşkanının topal ördek konumuna düşeceği ileri sürülmektedir.

Cumhurbaşkanlığı hükümet sistemiyle birlikte seçim kanununda yapılan değişiklikle birlikte siyasi partilerin ittifak yaparak seçimlere girmesi düzenlenmiştir. Yapılan düzenlemeyle birlikte \%10 seçim baraj1 etkisiz hale gelmekte ve ittifaklar sayesinde küçük partilerin de mecliste yer bulması mümkün hale gelmektedir. 24 Haziran seçimi sonrasında Ak 
Parti'nin 295 milletvekilinde kalması, mecliste çoğunluğu sağlayabilmek için MHP'nin desteğine bağımlı hale gelmesine yol açmıştır. Türkiye'nin siyasi parçalanmış yapısı göz önüne alındığında, parti ittifakların ömürlerinin yeni sistemin başarısını daim kılacak bir alt yapıya sahip olmadığı görülmektedir. Dolayısıyla muhalif partiler, Cumhurbaşkanı Recep Tayyip Erdoğan'ın yasama erkinin desteğini alabilmesi için MHP'nin beklentilerini dikkate alacağını ve nihayetinde iktidarı MHP'yle paylaşmak zorunda kalarak "topal ördek” durumuna düşeceğini ileri sürmektedir.

CHP Genel Başkanı Kemal Kılıçdaroğlu 24 Haziran yasama-yürütme seçimleri sonrasında yaptı̆̆ topal ördek açıklaması; her ne kadar Cumhurbaşkanı Recep Tayyip Erdoğan'ı hedef alsa da, aslında başından beri parti olarak karşı oldukları cumhurbaşkanlığ hükümet sisteminin ilk seçimde kriz üretmeye başladığı tezini dile getirmek amacını taşımaktadır. Bu noktadan cumhurbaşkanlığ1 hükümet sisteminde cumhurbaşkanı seçilebilmek için adayların $\% 50+1$ oya ihtiyaçları bulunmaktadır. Böylesine bir düzenlemede CHP'nin ittifaklar olmadan bu oya ulaşması mümkün değildir. Parlamenter sistemin uygulamada defalarca sistemin kilitlenmesine de sebep olan yönetsel ve siyasi krizlere gebe kalmış olmasına rağmen, eski sistemde ayak diretmesi Türkiye gerçeğiyle bağdaşmamaktadır. Nihayetinde Türkiye'ye özgü olarak tasarlanan cumhurbaşkanlığ 1 hükümet sisteminin, uygulamada bazı sıkıntılar ile karşılaşması doğaldır. Ancak sahada ortaya çıkan sorunların iktidar-muhalefet partilerinin konsensüs halinde çözüme kavuşturması, milletin talep ve beklentilerine daha uygun düşmektedir.

\subsection{Topal Ördek Tartışmaları Bağlamında Cumhurbaşkanlığı Hükümet Sisteminde Olası Riskler ve Karşı Çözümler}

24 Haziran 2018 yasama-yürütme erklerinin seçimlerinden sonra Türkiye gündemine taşınan "topal ördek" vakası, başkanlık sisteminin temel özellikleri üzerinde yükselen cumhurbaşkanlığı hükümet sistemi açısından benzer bir risk oluşturup oluşturmadığ yeni sistemin başarısı açısından son derece önemlidir. Bu bağlamda kamuoyu nezdinde çok geniş bir platformda tartışılan yeni sistem; yürütme erkinin tek başlı1ığı, yasama-yürütme erklerinin millet tarafindan seçilmesi ve devletin sahip olduğu erklerin görev ve yetkilerin net bir şekilde tanımlanması bakımından başkanlık sistemine yakın düzenlemeler içermektedir. Her ne kadar yeni sistem ABD tipi başkanlık sistemine yakın düzenlemeler içerse de, başkanlık sisteminde görülen sıkıntıların giderilmesi adına Türkiye'ye özgü yeniden tasarlanmıştır. Dolayısıyla yeni sistemde denge ve denetleme mekanizmaları açısından yasama ve yürütme erklerinin birbirlerini gözetlemesi başkanlık sistemine göre farklılık arz etmektedir (Akınc1, 2019:2108-2124).

Başkanlık sisteminde "topal ördek" vakasına sebep olan durumların incelenmesinde, sistemin temel özelliklerinin öne çıktığı görülmektedir. Yasama-yürütme erklerinin belirli süreler için millet tarafından seçilmesi başkanlık sisteminin doğasında bulunmaktadır. Dolayısıyla başkanlık sisteminde yürütme erkinin başı olan başkan en fazla iki dönem için görev yapabilmektedir. İkinci dönemin sonunda bütün başkanlar tekrar seçilemeyeceğini en baştan bilmektedir. Ayrıca başkanlık sisteminde yasama ve yürütme erklerinin seçimleri farklı zamanlarda yapılmakta ve böylelikle farklı dönemlerde ortaya çıan siyasi gelişmelerin temsili mümkün hale gelmektedir. Ancak başkanlık sisteminin uygulamasında sıkıntı yaratan topal ördek vakası, başkanının ve kongre üyelerinin haleflerinin seçilmesi noktasında geçiş sürecinden kaynaklanan tablo ile başkanının partisinin kongre karşısında çoğunluğu kaybetmesi durumlarında ortaya çıkmaktadır. Türkiye'de 24 Haziran seçimlerinden sonra tartışılan bu vakanın; cumhurbaşkanlığ hükümet sisteminde de benzer şartların oluşması halinde sistem adına bir risk oluşturup oluşturmadığı ve böylesine bir risk halinde sistemin rahat çalışması için ne gibi önlemler alındığ maddeler halinde aşağıda açıklanmıştır.

Kuvvetler ayrılığının net olduğu başkanlık sisteminde, yasama ve yürütme erkleri birbirlerinin ne görev alanına ne de hukuki varlıklarına müdahale edememektedir. Burada tek istisna başkanının kongre tarafından suçlanması (impeachment) sonucu azledilmesidir. Başkan bunun dışında kesintisiz görevine devam etmektedir. Bununla birlikte başkan ikinci döneminin 
sonunda halefi göreve başlayıncaya kadar geçirdiği dönemde topal ördek olarak anılmaktadır. Burada selef başkan halefi göreve başlayıncaya kadar yaklaşık üç ay daha görevine devam etmektedir. Şüphesiz bu süre başkanın popülist bir yönetim tarzı uygulayabilecek olması durumunda sistem adına risk teşkil etmektedir. Cumhurbaşkanlığı hükümet sisteminde yürütme erkinin baş1 $5+5$ iki dönem görev yapabilmektedir. Ancak yasama erkinin vereceği seçimleri yenileme kararı sonrasında seçimlere bir yıldan fazla süre kalmışsa cumhurbaşkanı bir dönem daha aday olabilmektedir. 24 Haziran seçimlerinden sonra yapılan topal ördek tartışmalarında ise cumhurbaşkanının seçimler yoluyla ister birinci isterse de ikinci döneminin sonunda görevi halefine bırakacak olması noktasındaki geçiş süreleriyle alakalı bir eleştiri bulunmamaktadır. Çünkü yeni sistemde halef cumhurbaşkanı seçim kararının YSK tarafından açıklanması ve mazbatasını almasıyla birlikte mecliste yemin ederek derhal görevine başlamaktadır. Örneğin yeni sistemin ilk genel seçimi olan 24 Haziran seçimlerinden sonra cumhurbaşkanı olan Erdoğan, yaklaşık iki hafta sonra 09 Temmuz 2018'de görevine başlamıştır. Dolayısıyla başkanlık sisteminde geçiş dönemlerinde yaşanan topal ördek vakası, cumhurbaşkanlığı hükümet sisteminde öngörülen sürelerin çok kısa olması nedeniyle daha az risk teşkil etmektedir.

24 Haziran tartışmalarına konu olan topal ördek tartışmalarında başkanlık sistemi açısından öne çıkan bir diğer husus, başkanın kongrede parti çoğunluğunu kaybetmesi halidir. Bu noktadan başkanlık sisteminde başkanın kongredeki siyasi parti çoğunluğunu kaybetmesi durumunda yasama-yürütme ilişkileri açısından zor bir dönem yaşanması kaçınılmazdır. Yaşanacak en can alıcı durum ise, başkanın kongre tarafından daha rahat suçlanmasıdır. Böylesine bir tablo halinde temsilciler meclisinin salt çoğunluğu ve senatonun 2/3'ünün onayıyla verilecek politik bir karar, sistemin kuvvetler ayrılığı prensibine gölge düşürecektir (Onar, 2005:93-96). Yine başkanın bakan ve üst düzey yöneticileri atarken senato onayına ihtiyaç duyması, kendi ekibini kurması noktasında bile engellemelerle karşı karşıya kalmasına sebep olabilecektir (Beceren ve Kalağan, 2007:164-180). Ayrıca kongrenin sayısal çoğunluğunun başkanın aleyhinde olması halinde yürütme erki açısından hayati konumda olan bütçenin de onaylanmama riskini beraberinde getirmektedir. ABD'de sırf bu yüzden başkan ile kongre arasındaki çekişmeden kaynaklanan bütçe krizlerinde, bazı kamu kurumlarının hizmeti durdurduğuna bile şahit olunmaktadır. Bir diğer restleşme ise başkanın yasama faaliyetlerini engelleyebilecek veto yetkisinin bulunmasıdır. Başkanın veto ettiği kanunlar 10 gün içerisinde her iki meclisin 2/3'ü tarafından tekrar kabul edilmesi gerekmektedir. Ancak meclisin bu sayıya ulaşması siyasi konjonktür açısından çok zor bir durumdur. Dolayısıyla başkanlık sisteminde başkanının kongrede üstünlüğünü kaybetmesi, birçok alanda sistemin uyumlu çalışmasını baltalamaktadır (Kuzu, 2013:39-41). Cumhurbaşkanlığ hükümet sisteminde de, benzer bir durumda cumhurbaşkanı ile meclis arasında böylesine bir restleşmenin olması mümkündür. Dolayısıyla 24 Haziran seçimlerinden sonra muhalif partiler tarafından ortaya atılan topal ördek vakası, Cumhurbaşkanı Recep Tayyip Erdoğan'ın genel başkanı olduğu partisinin mecliste tek başına çoğunluğu sağlayamamasıyla doğrudan ilgilidir. CHP Genel Başkanı Kemal Kılıçdaroğlu'nun Cumhurbaşkanı Recep Tayyip Erdoğan için dile getirdiği "topal ördek" vakası, aslında Cumhurbaşkanı Recep Tayyip Erdoğan'ın partisinin mecliste çoğunluğu sağlayamaması üzerine kurgulanmıştır. Öyle ki mecliste çoğunluğunu kaybeden Cumhurbaşkanı Recep Tayyip Erdoğan, yürütmeyle alakalı konularda ihtiyaç duyacağı yapısal dönüşümleri partisinin desteğiyle bile olsa artık meclisten çıkartamayacaktır. Ancak başta CHP olmak üzere diğer muhalif partilerin bu tezi, seçim sisteminde yapılan değişiklik sonucunda partilerin ittifak kurmalarının önünün açılmasıyla anlamsız hale gelmiştir. Çünkü yasama ve yürütme erklerinde söz sahibi olmak isteyen partiler, yeni sistemle birlikte mutlaka birbirleriyle ittifak kurmak zorundadır. Türkiye'nin siyasi yapısı gereği hiçbir partinin herhangi bir ittifak içerisinde olmadan hedeflerine ulaşması zor gözükmektedir. Dolayısıyla 24 Haziran seçimlerine cumhur ittifakı adı altında giren Ak Parti ve MHP, yasamada oluşturmuş olduğu birliktelik ile yasama-yürütme ilişkilerinin sağlıklı bir zeminde yürümesi için gerekli olan sinerjiyi ortaya koymuştur. Bununla birlikte yeni sistemde Türkiye'nin siyasi parçalanmışlıklarını göz önüne 
alınarak, ittifakların başarısız olması durumunda yaşanacak yasama-yürütme restleşmesinde sistemin tıkanmasını önlemek adına bir dizi önlemler alınmıştır. Bunların başında yürütme erki için hayati konumda olan bütçenin meclis tarafından onaylanmaması halinde, bir önceki yılın bütçesinin yeniden değerleme oranında artırılarak cumhurbaşkanı tarafından kullanılmasının önü açılmıştır. Böylelikle cumhurbaşkanı yasamadaki çoğunluğunu kaybetse bile, bütçeyi kullanabilmekte ve kamu hizmetlerini sunmaya devam edebilmektedir. Yeni sistemde ayrıca bakanların ve üst düzey yöneticilerin atanması noktasında başkanlık sisteminde olduğu gibi meclisin onayına gerek yoktur. $\mathrm{Bu}$ noktadan cumhurbaşkanının ekibini kurarak, siyasal sorumluluğunu mazerete mahal vermeden tam olarak yerine getirmesindeki engellemeler ortadan kaldırılmıştır. Yeni sistemde cumhurbaşkanının yasama faaliyetleri engellemek için veto yetkisini kullanması halinde meclisin salt çoğunluğu ile tekrar kabul edilmesi gerekmektedir. Ancak yeni sistem başkanlık sisteminde başkanın veto yetkisini kullanması halinde istenen 2/3 oranına göre daha düşük bir oran belirlemiştir. Dolayısıyla yeni sistemde cumhurbaşkanının meclisteki çoğunluğunu kaybetmesi durumunda bu yetkisini kullanmas1, meclis üstünlügünü ele geçiren muhalif partiler tarafindan rahatlıkla egale edilebilecektir.

Başkanlık sisteminde topal ördek vakasının ortaya çıkmasında bir diğer önemli unsur seçimlerin farklı zamanlarda yapılmasıdır. Yasama ve yürütme erklerinin seçimlerinin farklı zamanlarda yapılması, başkanın partisinin değişen siyasi atmosfere göre desteğin azalması ve buna bağlı olarak meclisteki çoğunluğunu kaybetme riskini beraberinde getirmektedir. ABD'de son elli yılda yapılan ara seçimlerde böylesine bir tabloyla karşılaşmak neredeyse sıradanlaşmıştır. Özellikle senatonun her iki yılda bir yapılan seçimlerle 1/3'ünün değişmesi, başkanın mevcut durumunu bir anda değiştirmektedir. Öyle ki yapılan ara seçimlerde başkanın partisinin seçimleri kaybetmesi, başkan ile kongrenin birçok konuda karşı karşıya gelmesine sebep olabilmektedir. Dolayısıyla başkanlık sisteminde ortaya çıkan bu tabloda, başkanın topal ördek konumuna düşmesi olağan bir durum olarak nitelenmektedir. Cumhurbaşkanı hükümet sisteminde de yasama ve yürütme erkleri net bir şekilde ayrılmış olmakla birlikte, seçimleri eş zamanlı olarak yapılmaktadır. Yasama-yürütme erlerinin seçimlerinin eş zamanlı olması, siyasi konjonktürün hem yasamada hem de yürütme erkinde benzer çoğunluklara sahip olmasını kolaylaştırmaktadır. Yeni sistemde eş zamanlı seçimlerin yanı sıra, her iki erke de sistemin tıkanması halinde seçimleri yenileme yetkisi verilerek sistemin rahatlatılması amaçlanmıştır. Burada kuvvetlerin birbirini feshinden ziyade, seçimlerin karşılıklı yenilenmesi söz konusudur. Nihayetinde hangi erk seçim kararı alırsa kendi seçimini de yenilemiş olmaktadır. Tabi ki burada cumhurbaşkanının tek bir kişi olarak seçimleri yenileme yetkisini meclise göre daha rahat kullanması olasıdır. Sonuç olarak cumhurbaşkanlığı hükümet sisteminde yapılan eş zamanlı seçimler ve erklere tanınan seçimleri yenileme yetkisi, sistemin topal ördek yaratma riskini minimize etmektedir.

\section{Sonuç ve Değerlendirme}

Türkiye'de uygulanmakta olan parlamenter hükümet sistemi, ortaya koyduğu performans çıktıları göz önüne alındığında kendisinden beklenen işlevleri bir türlü yerine getiremediği görülmektedir. Bütün ülkeler küresel arenada baş döndüren değişimlere karşı yürütme erklerini güçlü ve etkili tutarak zamana ve mekâna ayak uydurabilme yarışına girmiş iken, yönetsel kriz sarmalı ve kendi iç sorunlarını bir türlü çözemeyen Türkiye ise çevresinde olup bitenlere karş1 güçlü refleks göstermekten gün geçtikçe uzaklaşmıştır. 16 Nisan 2017 tarihinde yapılan referandum ile Türkiye'de bu duruma kayıtsız kalmayarak temelleri ABD başkanlık sistemi üzerine kurulan "Cumhurbaşkanlığı Hükümet Sistemine" yeşil 1şık yakmıştır. 24 Haziran 2018 genel seçimiyle birlikte tam manasiyla uygulanmaya başlanan yeni sistem, daha referandum öncesinden yasamayürütme-yarg1 erkleri üzerinden başlayan çok boyutlu tartışmalara da kapı aralamış ve nihayetinde muhalif partilerin seçim sonuçları sonrasında Cumhurbaşkanı Erdoğan için "topal ördek" çıkışıyla yeni bir boyut kazanmıştır. Topal ördek kavramı her ne kadar İngiltere'de ortaya çıkmış ise de, zamanla politik alana geçerek ABD'de başkanın kongre karşısındaki çoğunluğunu kaybetmesi durumunu ifade eden bir kavram haline dönüşmüştür. Bununla birlikte dört yıllık sürelerle iki

Turkish Studies - Economy, 15(1) 
dönem için seçilen başkanın, ister birinci isterse de ikinci dönemin sonunda halefinin seçilmesi durumunda, yeni başkanın görevine başlayıncaya kadar geçen süredeki durumu da topal ördek olarak tanımlanmaktadır.

Türkiye'de ise CHP Genel Başkanı Kemal Kılıçdaroğlu'nun 24 Haziran 2018 yasamayürütme erklerinin seçimleri akabinde başlattığı topal ördek tartışması, Cumhurbaşkanı Recep Tayyip Erdoğan'ın 31 Mart yerel seçimleri sonucu üzerinden karşı “topal ördek” çıkışıyla devam etmiştir. Her iki liderin de topal ördek vakası ile ilgili ileri sürdügü tezler, seçim sonuçlarının politik değerlendirmesinden ibarettir. Muhalif partilerin bu konudaki argümanlarına bakıldığında, yeni hükümet sistemin ilk genel seçimi olması münasebetiyle cumhurbașkanının değișiminden ziyade, meclis çoğunluğunun cumhurbaşkanının partisinin aleyhinde olması üzerine kurgulanmıştır. $\mathrm{Bu}$ noktadan muhalif partiler 24 Haziran 2018 yasama-yürütme erklerinin seçimlerinde ortaya çıkan sonuçların, başkanlık sisteminde başkanının kongredeki çoğunluğunu kaybetmesi sonucunda düştüğü "topal ördek" vakasıyla benzerlik arz ettiğini ileri sürmektedir. Ancak yeni hükümet sistemiyle birlikte seçim kanunlarında yapılan değişiklikler sonucunda siyasi partilerin ittifak kurarak seçimlere girebilmesi mümkün hale gelmiştir. Dolayısıyla her ne kadar Cumhurbaşkanı Recep Tayyip Erdoğan'ın partisi olan Ak Parti mecliste tek başına çoğunluğu elde edememiş olsa da, MHP ile kurdukları cumhur ittifakının mecliste çoğunluğu elde etmesi muhalefet partilerinin bu argümanını şimdilik havada bırakmaktadır. Diğer taraftan seçim ittifakların bir seçim dönemi boyunca kesintisiz devam edeceğine yönelik bir düzenlemenin olmaması, cumhurbaşkanlığı yarışını kazanan her siyasi partinin yasama erkinde de mutlak zaferle çıkmasını gerekli kılmaktadır. Aksi halde muhalefet partilerinin ileri sürdüğü tarzda "topal ördek" vakasının gerçekleșme riski oldukça yüksek olacaktır. Bu riski minimize edebilmek adına siyasi partilerin mümkün olduğunca mevcut seçim ittifaklarını güçlendirecek uygulamaları bir an önce hayata geçirmeleri büyük önem arz etmektedir.

Nihayetinde yeni sistemin kurgulanması aşamasında Türkiye'nin siyasi yapısı göz önüne alınarak, yürütme erkinin elini güçlendiren bazı düzenlemeler sayesinde cumhurbaşkanının "topal ördek" durumuna düşmesi önlenmek istenmiştir. Bu bağlamda cumhurbaşkanının partisinin mecliste yeterli çoğunluğu elde edememesi durumunda cumhurbaşkanına verilen yetkiler sayesinde, ABD başkanlık sisteminde sistemin kilitlenmesine yol açabilecek bütçe krizlerinden, bakan ve üst düzey kamu görevlilerin atanmasına ve hatta seçimlerin yenilenmesine kadar birçok sorunun yeni sistemle birlikte ortadan kaldırıldığı görülmektedir. Cumhurbaşkanlığ 1 Hükümet Sistemi'nde selef-halef başkanların değişimleri sırasında ABD başkanlık sistemine göre sürenin çok kısa tutulması da "topal ördek" vakasının Türkiye'de oluşmasını engelleyici bir düzenleme olarak karşımızda durmaktadır. Bununla birlikte uygulamada yeni olan cumhurbaşkanı hükümet sisteminin, Türkiye'de oturuncaya kadar "topal ördek" vakası gibi birçok sınamalardan geçeceği ve tartışmalara konu olacağı da beklenmelidir.

\section{Kaynakça}

Akınc1, B. (2019). The contribution of the presidential government system of the republic with specific design to Turkey to rationalize the presidential system, International Journal of Society Researches, 13(19), 2107-2124.

Akıncı, B. (2019). Cumhurbaşkanlığı Hükümet Sistemi: Sisteme Yönelik Eleştiriler ve Çözüm Önerileri, Nobel Akademik Yayıncılık, Ankara.

Akşener, M. (2019). Cumhurbaşkanı "Kazansalar Dahi Bunlar Topal Ördek" Demesi...,https://www.turkiyemtv.com.tr/haber/2472511/iyi-parti-lideri-aksenercumhurbaskani-kazansalar-dahi-bunlar-topal-ordek-demesihadsizligin-yansimasidir, Erişim Tarihi: 13.10 .2019 
Amedo, K. (2019). Lame Ducks: Presidents, Amendments, and Sessions, https://www.thebalance.com/lame-duck-definition-session-how-it-got-its-name-3306307, Erişim Tarihi:12.10.2019

Avcı, E. (2019). ABD'de “topal ördek" pozisyonunda başkan çok, https://www.aa.com.tr/tr/dunya/abd-de-topal-ordek-pozisyonunda-baskan-cok/103875, Erişim Tarihi:11.10.2019

Beceren, E. ve Kalağan, G. (2007). "Başkanlık ve Yarı Başkanlık Sistemi: Türkiye'de Uygulanabilirliği Tartışmaları”, İstanbul Ticaret Üniversitesi Sosyal Bilimler Dergisi, Yıl: 6, Say1: 11, ss. 163-181.

Cambridge Dictionary, https://dictionary.cambridge.org/tr/s\%C3\%B6z1\%C3\%BCk/ingilizce/lameduck, Erişim Tarihi:10.10.2019

Çisel $\dot{I}$. (2017). 20 Ocak: Beyaz Saray'da Trump Dönemi Başlarken, https://www.ikv.org.tr/icerik_print.asp?id=1751, Erişim Tarihi:11.10.2019

Erdoğan, R. T. (2019). "Erdoğan'dan İstanbul yorumu: Bunlar topal ördek", https://www.sozcu.com.tr/2019/gundem/erdogandan-istanbul-yorumu-bunlar-topal-ordek4286421/, Erişim Tarihi: 13.10.2019

Eren, V., Akıncı, B. (2018). Yasama Yürütme İlişkileri Açısından Başkanlık Sistemi İle Cumhurbaşkanlığı Hükümet Sisteminin Karşılaştırılması, Cumhurbaşkanlığı Hükümet Sistemi Kamu Yönetiminde Değişim, Ed. Yüksel Demirkaya, 1. Bask1, Hiperyayınları, İstanbul.

Gülener, S. (2016). Başkanlık Sistemlerinde Denge Ve Denetleme, Seta Yayınları: 66, I. Bask1, Ankara.

Johnson, S. K. (1986). The Portrayal of Lame-Duck Presidents by the National Print Media, Presidential Studies Quarterly, Vol. 16, No. 1, The Media And The Presidency (Winter, 1986), pp. 50-65.

Kahraman, M. (2012). "Hükümet Sistemi Tartışmaları Bağlamında Başkanlık Ya Da YarıBaşkanlık Sistemlerinin Türkiye'de Uygulanabilirliği”, Mustafa Kemal Üniversitesi Sosyal Bilimler Enstitüsü Dergisi, Y11/Year: 2012, Cilt: 9, Say1:18, s.431-457.

Kılıçdaroğlu, K. (2018). "Dünün tek adamı bugünün topal ördeğidir. Her istediğini yapamayacak", https://www.haberturk.com/kilicdaroglu-nun-erdogan-icin-kullandigi-topal-ordek-kavramine-anlama-geliyor-topal-ordek-ne-demek-2033020, Erişim Tarihi: 13.10.2019

Kuzu, B. (2013). Her Yönüyle Başkanlık Sistemi, Babıali Kültür Yayıncılığı, 3. Baskı, İstanbul.

Miş, N. ve Duran, B. (2017). Türkiye'de Siyasal Sistemin Dönüşümü ve Cumhurbaşkanlığı Sistemi, SETA Kitapları 19, 2. Bask1, Ankara.

Onar, E. (2005). Türkiye'nin Başkanlık veya Yarı-Başkanlık Sistemine Geçmesi Düşünülmeli Midir?, T. Ergül (Edt.), Türkiye Barolar Birliği Yayınları, Ankara.

Parsak, M. (2012). Parlamenter/Başkanlık/Yarı Başkanlık Hükümet Sistemlerine Genel Bir Bakış ve Türkiye Cumhuriyeti'nin Hükümet Sistemi, Türk Akademisi Siyasi Sosyal Stratejik Araştırmalar Vakfi, 1:1-20.

Potter, B. K. P. (2016). Lame-Duck Foreign Policy, Presidential Studies Quarterly 46(4), October 2016. 
Türkiye'de 24 Haziran 2018 Genel Seçimleri Sonrasında “Topal Ördek” Tartışması:...

Sall1 M. K. (2006). "Topal Ördek" Zorda Ama..., Kaynak: https://www.oncevatan.com.tr/topal-ordek-zorda-ama-makale,21445.html, Erişim Tarihi:12.10.2019

Sartori, G. (1997). Karşılaştırmalı Anayasa Mühendisliği, (Çev. Ergun Özbudun), Yetkin Yay., Ankara.

Yaman, A. (2014). Başkanlık Sistemi, Uygulamaları ve Türkiye'de Uygulanabilirliği, Fırat Üniversitesi Sosyal Bilimler Dergisi, Cilt: 24, Sayı: 1, Sayfa: 83-98.

Yazıcı, S. (2005). Başkanlık sistemleri: Türkiye için bir değerlendirme. T. Ergül (Edt.), Türkiye Barolar Birliği Yayınları, Ankara.

Yıldırım, H. (2017). Parlamenter Sistem Krizleri ve Cumhurbaşkanlığı Hükümet Sistemi, Pozitif Yayınları, 1. Bask1, İstanbul.

Yüksek Seçim Kurulu (2018). Cumhurbaşkanı ve 27.Dönem Milletvekili Genel Seçimi Milletvekili Seçimleri

Sonucu, http://www.ysk.gov.tr/doc/dosyalar/docs/24Haziran2018/KesinSecimSonuclari/2018MV96D.pdf, Erişim Tarihi: 13.10.2019

Yüksek Seçim Kurulu (2019). 31 Mart 2019 Mahalli İdareler Genel Seçimleri İstatistikleri, http://www.ysk.gov.tr/tr/istatistik/5644, Erişim Tarihi: 13.10.2019

7102 sayılı "Seçimlerin Temel Hükümleri ve Seçmen Kütükleri Hakkında Kanun ile Bazı Kanunlarda Değişiklik Yapılmasına Dair Kanun”, 13.03.2018. 